\title{
Spatial differences in migration of businesses: The example of Polish regions
}

\begin{abstract}
Companies relocate in various manners. Some of them move by way of foreign direct investments, other relocate within their countries, regions or local areas of operation (e.g. when a company moves its seat to a different street). This paper focuses on the issue of relocating companies' seats. Data analysis (on NUTS2 level) indicates that migration of companies leads to an increased concentration of businesses in the Mazovia region, in particular in Warsaw. Additionally, it was demonstrated that in all of the Polish voivodeships the majority of companies that migrate do so within their regions. The weakest "magnet" for businesses are the voivodeships belonging to the least developed areas in Poland (Eastern Poland) and the Opole voivodeship, which undergoes a significant decline in population.

Keywords

Relocation of companies - location factors - regional diversity • concentration $\cdot$ specialization
\end{abstract}

(C) University of Warsaw - Faculty of Geography and Regional Studies

Introduction

The migration of companies, conceived in this paper as a change in registered address, may have significant social and economic consequences. If the number of companies moving into a region exceeds the number of companies moving out of it, it may be explained by high competitiveness or attractive investment conditions (Jarczewski 2012; Wołowiec \& Skica 2013). In line with the principle of cumulative causation (Myrdal 1957), the appearance of new companies may bring numerous positive outcomes in the business, social and environmental sectors (Hudson 2000; Bajo-Rubio et al. 2010). The simple fact of relocating a business to another region, even if that region has a positive company migration balance, should attract the interest of local politicians. It is important to understand why businesses decide to migrate (Schmenner et al. 1987; Vanhove 2000).

The consequences of the migration of companies and capital are one issue (Dunning \& Lundan 2008); another is the directions of migratory flow and the scale of relocation (Canaleta et al. 2004). Identification of the destinations and scale of the migration of economic potential is often the subject of in-depth analyses that attempt to determine the patterns of decision-making among entrepreneurs. Such studies are carried out at both the global and local levels (Dicken 2011; Fallon \& Cook 2010).

This paper attempts to answer the following question: does migration of companies lead to increased concentration, or dispersion of economic activity? The answer to this question is not necessarily obvious. On one hand it is clear that urban agglomerations are important factors in the location of businesses, which plays into the hands of affluent regions in which numerous companies already operate (Badri 2007). On the other, regional differences in available public aid mean that we can expect that some entrepreneurs will decide to apply for such aid, and it is usually allocated to the most vulnerable regions (Almond et al. 2015).

\section{Wojciech Dziemianowicz}

Department of Local Development and Policy, Faculty of Geography and Regional Studies, University of Warsaw, Poland

e-mail:w.dziemianowicz@uw.edu.p

Received: 8 March 2018

Accepted: 11 June 2018
Territorial differences in entrepreneurial activity

The issue of location of companies can be analyzed from the perspective of the theory of location (McCann \& Sheppard 2003), or as a spatially differentiated process (Schmenner et al. 1987; Domański 2001). This gives rise to the question of why some companies locate their business in given regions while others set up their operations elsewhere (Hilber \& Voicu 2009; Eriksson et al. 2014). This in turn leads to comparisons on national and regional scales, usually involving analysis of factors that attract foreign capital (Dziemianowicz 1997), which often boil down to assessing the competitiveness of regions from the perspective of entrepreneurs.

In the context of analysing the location of companies at various scales (regional and local) one may invoke the principles of location put forward by Stafford (1972, in: Welmesley \& Lewis 1997), who identified four stages of the location process, with the assumption that there are differences between them depending (inter alia) on the industry in which a company operates. Special attention should be paid to stage one and stage four, because stages two and three are ruled by "traditional" principles taken from the theory of location: maximization of demand and minimization of costs. What occurs at stages one and four? The first stage can be described as expansion in situ; this involves taking a decision to change the region or municipality and to seek benefits in the area of business operations (usually benefits of scale). In such cases a company relocates only within a district of a given city. This stage may also apply to newly created microenterprises, which are usually initially set up in the entrepreneur's place of residence (Dziemianowicz et al. 2012). The fourth stage involves taking a final decision on location, preceded by choosing from several potential new locations for a business. Stafford claims that in stage four - in particular if more than one location qualified to this stage - entrepreneurs cannot apply economic results as a criterion, because they often yield similar results 
(identified in stages two and three). Therefore, in order to take the right decision, entrepreneurs apply the principle of maximization of psychological benefits. At that stage, so-called "soft location factors" start to play a significant role (Grabow et al. 1995).

Location choices made by companies are also affected by previous such decisions taken by others, i.e. their competitors, and companies in their value chains. Entrepreneurs - as Weber (1909) rightly noted when he described urban agglomeration as one of three factors affecting location - benefit from the possibility of cooperation, but also from competition in a limited space. Geographical proximity creates conditions for development of clusters (Porter 2001), as well as for gaining innovation-based competitive advantages (e.g. smart specializations - Foray 2015). Hence, naturally, economically developed municipalities and regions will continue to attract companies from less developed areas, as well as new investments (e.g. foreign direct investments) due to a massive concentration of possibilities for competition and cooperation, as well as access to workforce and knowledge. This process is to some extent countered by policies designed to attract capital in weaker regions, and by regional policies in individual states that create preferential conditions in less developed regions and municipalities. For those reasons the scale and dynamics of regional differences in entrepreneurial activity presents itself as a problem in the context of development policy. It is important for regional comparisons whether business activity fosters convergence or divergence on the regional level (Gawlikowska-Hueckel 2003). Despite the fact that spatial location of companies plays a role in the development of the entire country and individual regions, it may be stated that the measures taken so far in Poland to direct the flow of private investments (in particular foreign investments to less-developed Eastern Poland) have had little success (Dziemianowicz 1997; Domański 2001; Ambroziak 2014).

\section{Hypothesis}

This paper puts forward the following hypothesis: the moving of businesses operating in Poland has increased differences between regions, which means an increased concentration of businesses in several voivodeships.

\section{Data and methodology}

This paper was written on the basis of data obtained from the National Business Registry (REGON). Among all businesses registered in REGON, the companies that changed their registered address in 2014 were selected. In this case, the company's migration concerns the change of address from one commune to an address in another commune (sometimes in the same voivodeship). In total there were 74,512 such companies (which constitute $1.8 \%$ of all businesses registered in REGON). Next, it was checked in which region those companies were registered in 2016 . The advantage of choosing the companies that changed their address as the subject of this paper is that if a company moves, it allows us to assume that it is operating. It does not provide any information about the number of staff, or volumes, but what is known for sure is that the company's owner is running the business. ${ }^{1}$

In the analysis of changes in the spatial structure two measures were taken into account: coefficient of variation:

$V=\frac{\mathrm{s}}{\bar{x}} 100 \%$

where:

$\mathrm{s}-$ standard deviation,

$\bar{x}$ - arithmetic mean

and the ratio of maximum to minimum value (Max/Min).

${ }^{1}$ It must be kept in mind that REGON includes both active companies and entities that are not operating, as well as entities that registered but never started business, and entities that have suspended their business activity.
These measures are commonly applied in spatial analyses (e.g. ed. Strahl 2006).

The attempt to assess the scale and scope of regional differences was based on a comparison of the measures of concentration and migration of businesses and other selected socio-economical factors. In the analysis the following was taken into account:

- $\quad$ size of population, which reflects the demographic potential and allowed the authors not to calculate all values e.g. per capita;

- size of workforce, both in respect of the company's registered seat and the actual performance of work;

- number of companies with foreign capital, which reflects how attractive a given region is in the eyes of foreign investors;

- number of newly registered and deregistered companies in the REGON system, which illustrates the pace of economic changes in the region. It needs to be kept in mind that those companies are not migrating, but were entered in the register of businesses or struck off the register at the request of their owner.

The structure of the companies

Most of the companies that relocated in the years 2014$2016^{2}$ belong to category $\mathbf{G}$ - wholesale and retail trade; repair of vehicles (including motorcycles) (Fig. 1). Category $\mathbf{M}$ comes second (professional, scientific and technical activity) and construction (category $\mathbf{F}$ ) is third (all of the remaining categories have a share of less than $10 \%$ ).

Category $\mathrm{G}$ is the dominant one among relocating companies in all voivodeships (it has the highest share in the Łódzkie voivodeship, at $29.0 \%$, and the lowest in the Dolnośląskie voivodeship, at $19.9 \%$ ). Category $\mathrm{G}$ includes trading companies and repair services. Their high activity in changing location may result from the frequent development cycle of small companies, which at some point are looking for closer contact with the market. This does not necessarily mean a change of location over a long distance (see Wilk 2001).

$76.5 \%$ of businesses that change their seats are sole traders, while a further $18.4 \%$ are legal persons, and the remaining $5.1 \%$ are entities without legal personality.

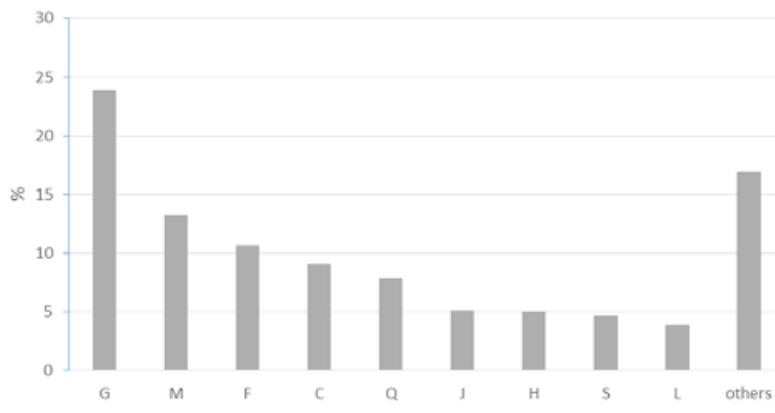

Figure 1. Share of categories listed in the Polish Classification of Business Activity (PKD) in the companies that relocated (\%) in 2014. Full names of categories: $C$ - industrial processing; $F-$ construction; $G$ - wholesale and retail trade; repair of vehicles, including motorcycles; $\mathrm{H}$ - transport and storage; $\mathrm{J}$ - information and communication; $L$ - activity related to providing services on the real estate market; $M$ - professional, scientific and technical activity; $Q$ - healthcare and social work; $S$ - other service activity. 


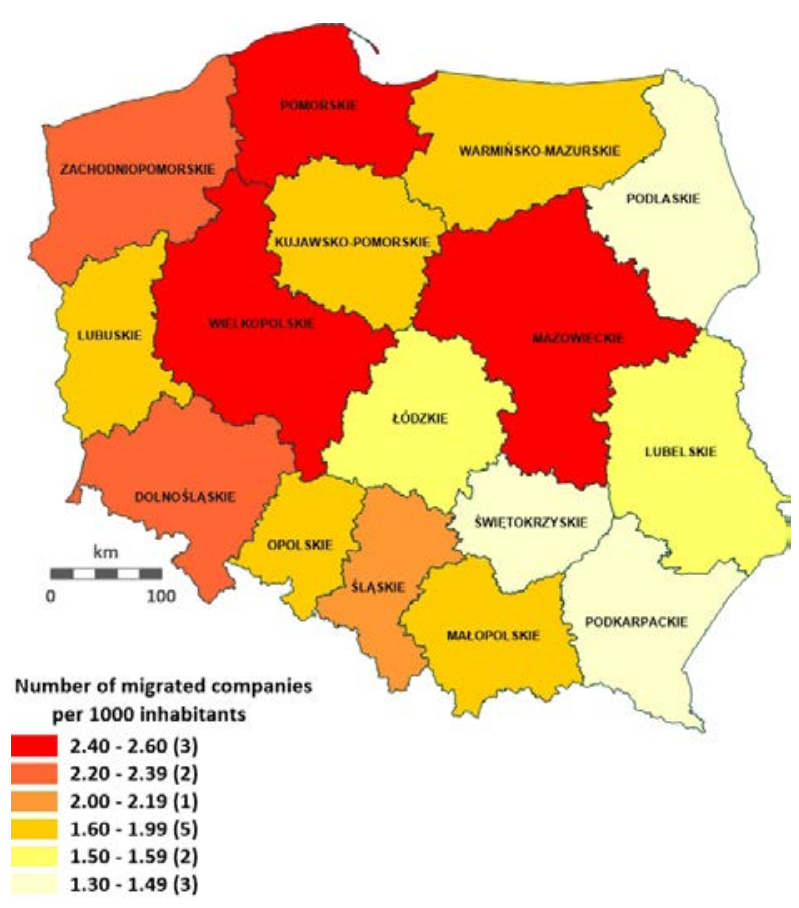

Map 1. Number of migrated companies per 1,000 inhabitants in 2014. Source: own analysis on the basis of the data from GUS (Central Statistical Office)

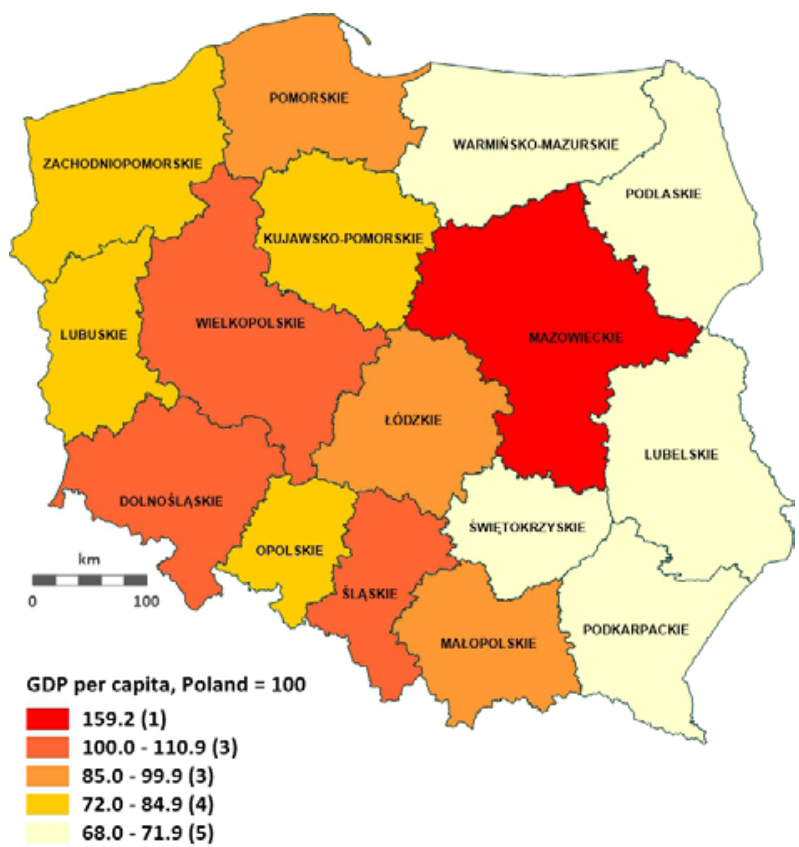

Map 2. Spatial distribution of companies that, following changes in 2014, had moved to a different gmina by 2016 ("inflow" from inside and outside of voivodeship) (Poland=100). Source: own analysis on the basis of data from GUS (Central Statistical Office)

Mobility of companies in the regional perspective

The diversification of voivodeships in terms of the number of companies relocating their activities in 2014 per 1,000 population is relatively small (Map 1). However, it should be emphasized

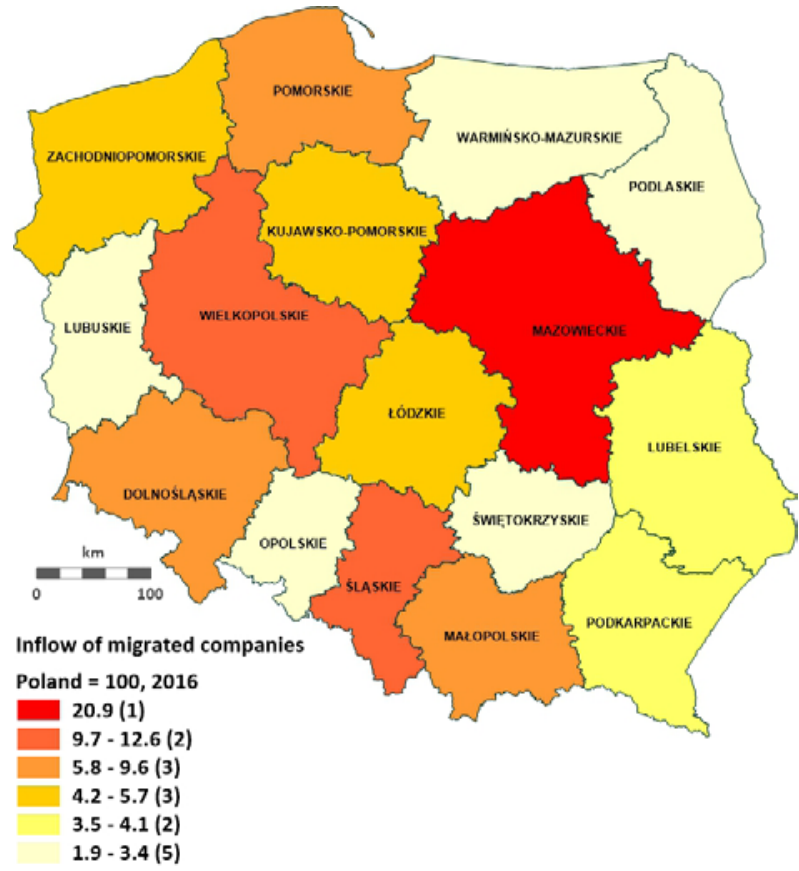

Map 3. GDP per capita in 2016, Poland $=100$ (in current prices). Source: own analysis on the basis of data from GUS (Central Statistical Office)

that the Mazowieckie voivodeship alone accounted for $17.5 \%$ of all relocating companies. Two years later, the Mazowieckie voivodeship has the largest share in the distribution of transferred companies, but it is higher than in 2014 and reaches almost $21 \%$ (Map 2). It is followed by two "metropolitan voivodeships" (Wielkopolskie and Pomorskie). The lowest percentage of relocated companies in Poland is reported in three voivodeships in Eastern Poland (Świętokrzyskie, Podlaskie and WarmińskoMazurskie) and in two provinces of western Poland with a relatively low level of socio-economic development (Opolskie and Lubuskie). It should be emphasized that the regional differentiation of GDP per capita in Poland is stable long-term, and for many years the Mazowieckie voivodeship has been in first place, while in last place is Eastern Poland (the Lubelskie, Podkarpackie, Podlaskie, Świętokrzyskie and Warmińskomazurskie voivodeships) (Map 3).

Company migration balance per 10,000 businesses in the years 2014-2016 (Map 4) demonstrates not only an increase in the economic potential of the Mazowieckie voivodeship, but also the fact that only four voivodeships can boast a positive external migration balance. The three voivodeships that report the worst results in terms of negative company migration balance with respect to the number of companies are Lubelskie, Podlaskie and Świętokrzyskie - all of them located in Eastern Poland.

Flows of companies within and between regions

In each of the voivodeships the majority of companies that moved their seats had originally been based in the same region (migration within voivodeships - see Map 5.) In some instances this is associated with a change of address within a large municipality. For instance, in Warsaw about 15,600 companies relocated from one district to another, and this number constitutes $49.9 \%$ of the companies that found themselves in this voivodeship as a result of relocation (the force of attraction of Warsaw will be discussed later in this paper). What are also noticeable are 


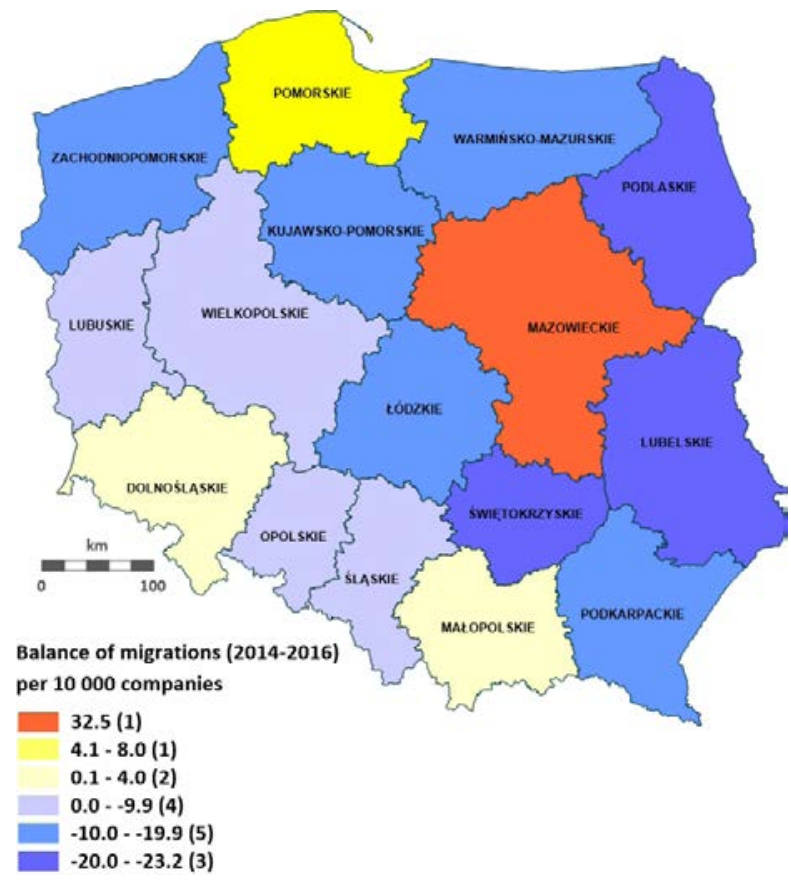

Map 4. External migration balance per 10,000 business entities (2014-2016). Source: own analysis on the basis of data from GUS (Central Statistical Office)

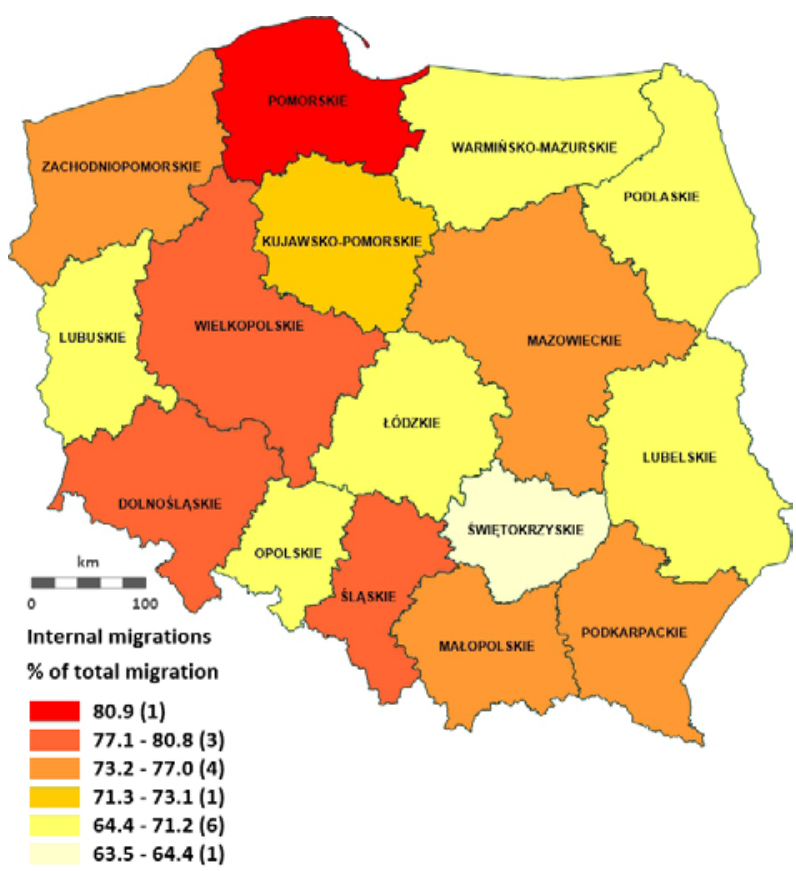

Map 5. \% of companies relocating within a voivodeship. Source: own analysis on the basis of data from GUS (Central Statistical Office)

Table 1. Share of cities in migration of companies to other cities in Poland (relocation of companies in the years 2014-2016)

\begin{tabular}{|c|c|c|c|c|c|c|c|}
\hline \multirow{3}{*}{$\begin{array}{l}\text { Location in } \\
\quad 2014\end{array}$} & \multicolumn{7}{|c|}{ Destination in 2016} \\
\hline & Warsaw & Gdańsk & Katowice & Kraków & Łódź & Poznań & Wrocław \\
\hline & \multicolumn{7}{|c|}{$\%$ of total inflow of migrated companies } \\
\hline Warsaw & & 8.7 & 9.7 & 9.5 & 14.6 & 8.7 & 8.6 \\
\hline Gdańsk & 2.1 & & 0.7 & 0.3 & 0.6 & 0.5 & 0.7 \\
\hline Katowice & 1.4 & 0.2 & & 2.7 & 1.8 & 0.8 & 0.9 \\
\hline Kraków & 3.6 & 1.6 & 4.6 & & 1.3 & 0.8 & 2.3 \\
\hline Łódź & 2.6 & 0.4 & 0.9 & 0.6 & & 0.7 & 1.2 \\
\hline Poznań & 4.7 & 1.9 & 2.2 & 2.0 & 2.7 & & 3.1 \\
\hline Wrocław & 3.4 & 1.5 & 1.2 & 1.7 & 1.3 & 1.8 & \\
\hline
\end{tabular}

Source: own analysis on the basis of data from GUS (Central Statistical Office)

migrations within urban and rural municipalities - moving from a city to the rural part of the municipality and vice versa. This data indicates that, again, regions with a high level of economic development and associated with major urban agglomerations are the strongest in attracting their "own" companies, while in less developed regions this force is much less strong.

Therefore, it is important to investigate migration flows within voivodeships, bearing in mind that the majority of relocations take place internally, within regions. Map 6 illustrates the situation in all Polish voivodeships; please note that it shows the size of internal migration and the share of a given voivodeship in the total outflow of companies from other voivodeships. These results lead to two key conclusions.

The first is that the Mazowieckie voivodeship has a unique position. It attracts the majority of companies relocating from all Polish regions. In six voivodeships up to $10-20 \%$ of companies that decided to relocate chose the Mazowieckie region as their final destination.
The second conclusion relates to the neighborhood effect (geographical proximity). In all Polish voivodeships there is one region that attracts the majority of companies migrating from its neighbors. The Mazowieckie voivodeship can be mentioned again as the region that attracts the largest percentage of companies migrating from other voivodeships, in particular from the less developed voivodeships in Eastern Poland. The conclusion presented above also applies in the less developed voivodeships.

In several cases the "metropolitan character of a voivodeship", i.e. the fact that a major metropolis is located in a voivodeship, was used to explain the observed spatial distribution. Analysis of data on the migration of companies between major cities in Poland (see Table 1) not only corroborates this assumption, but also sheds some light on the occurrences within the voivodeships. The data on companies migrating between seven metropolitan cities indicates that Warsaw is the main magnet for companies (see Map 7), while the exchange between other cities is rather limited. 

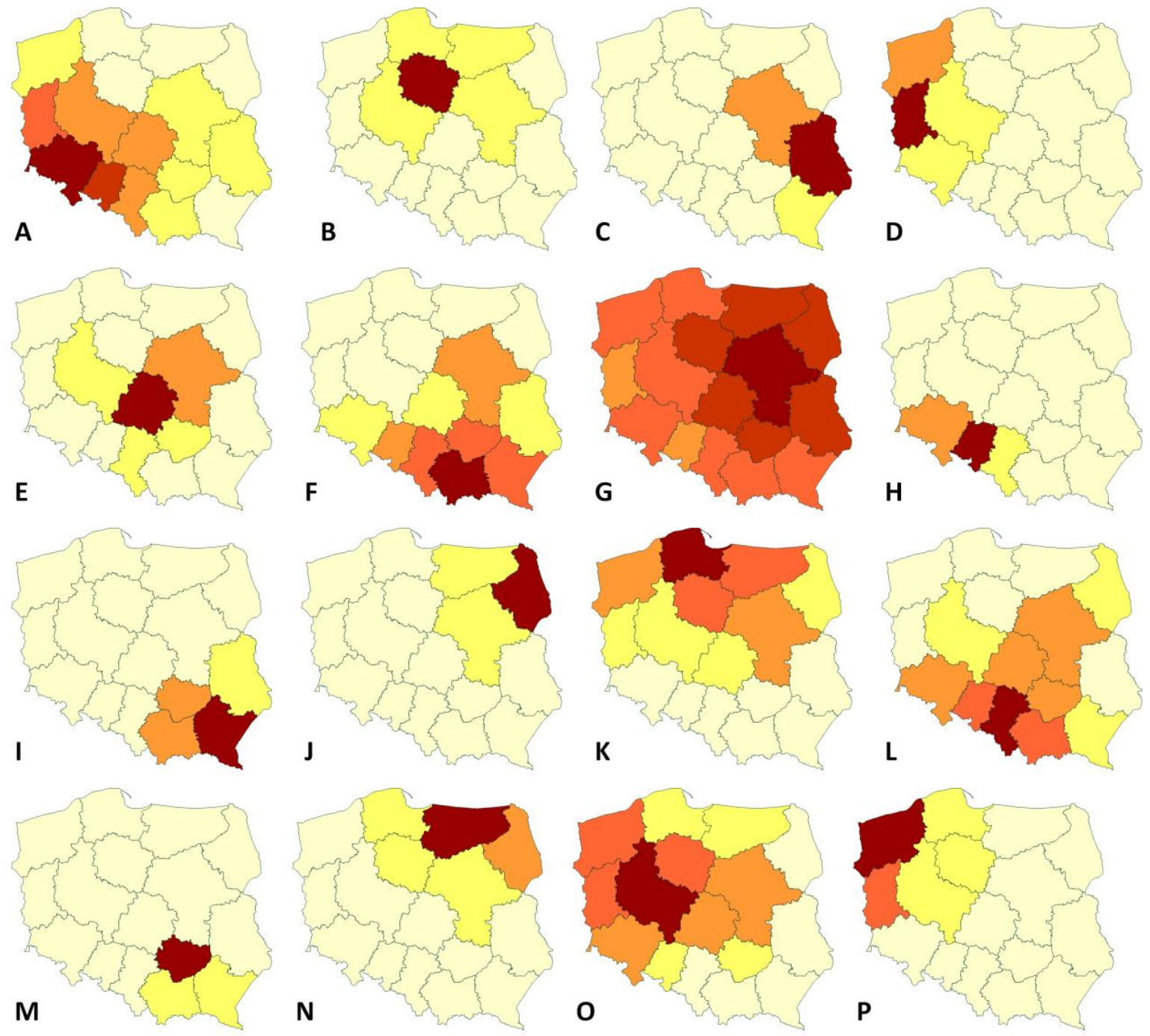

$\stackrel{\mathrm{km}}{200}$

\section{Internal migrations (\%)}

$63.5-80.9$

Share of the voivodship in the outflow of companies

from other regions

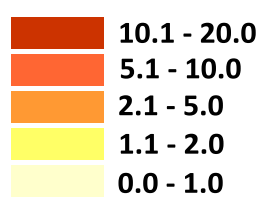

Voivodeships:

A - Dolnośląskie; B - Kujawsko-pomorskie; C - Lubelskie; D - Lubuskie; E - Łódzkie; F - Małopolskie; G - Mazowieckie; H - Opolskie; I - Podkarpackie; J - Podlaskie; K - Pomorskie; L - Śląskie; M - Świętokrzyskie; N - Warmińsko-Mazurskie; O -Wielkopolskie; P - Zachodniopomorskie

Map 6. Size of internal migration and participation of voivodeships in the outflow of companies from other voivodeships (\%). Source: own analysis on the basis of data from GUS (Central Statistical Office) 


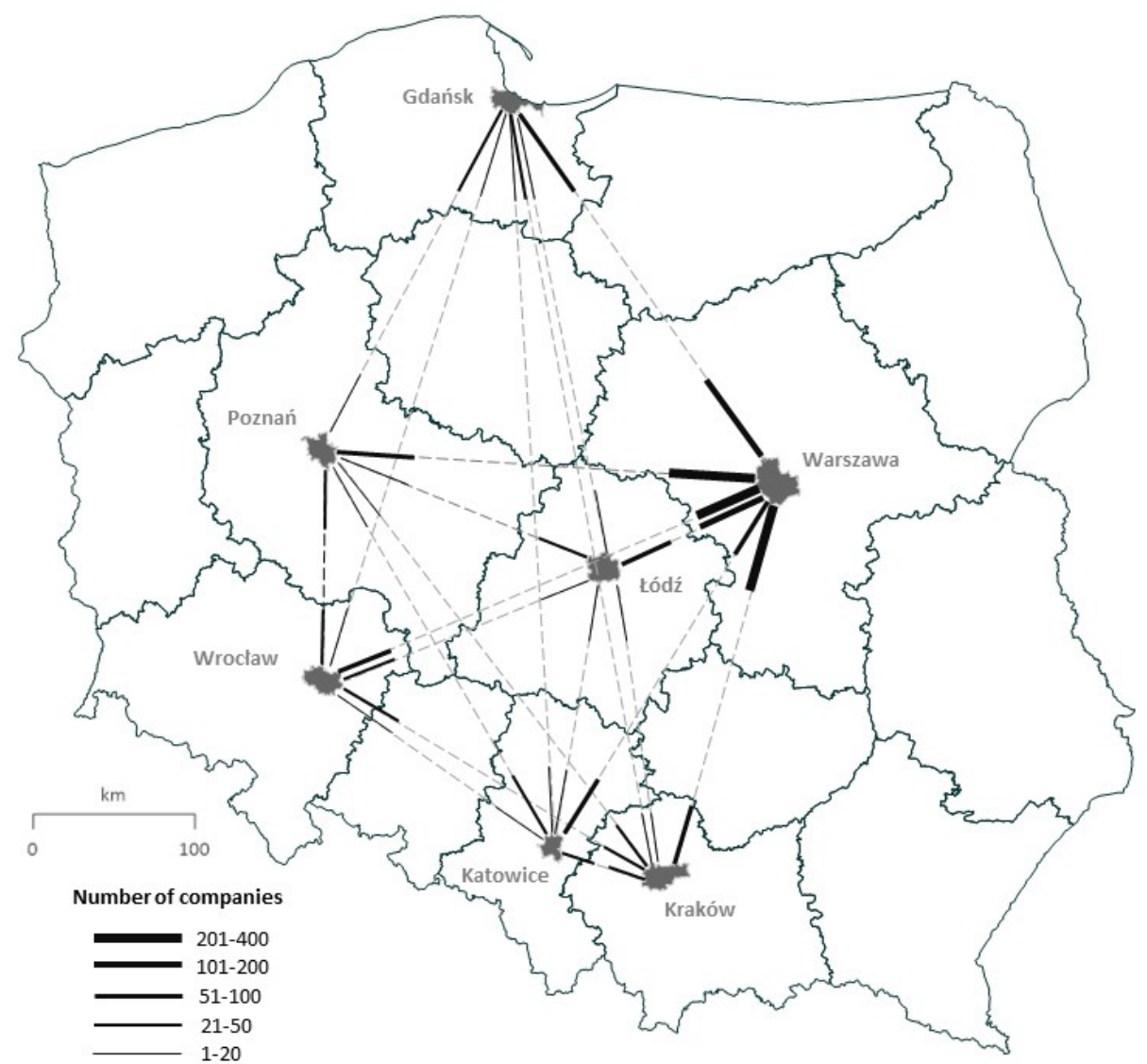

Map 7. Flows of companies between main cities in Poland (the wide lines near each city indicate the inflow of companies to this city from a given other city). Source: own analysis on the basis of data from GUS (Central Statistical Office)

Table 2. Measures of concentration of phenomena

\begin{tabular}{|c|c|c|c|c|c|c|}
\hline & \multicolumn{2}{|c|}{$\begin{array}{c}\text { Coefficient of } \\
\text { variation }\end{array}$} & \multicolumn{2}{|c|}{ Max / Min } & \multicolumn{3}{c|}{ Average } \\
\cline { 2 - 7 } & $\mathbf{2 0 1 4}$ & $\mathbf{2 0 1 6}$ & $\mathbf{2 0 1 4}$ & $\mathbf{2 0 1 6}$ & $\mathbf{2 0 1 4}$ & $\mathbf{2 0 1 6}$ \\
\hline $\begin{array}{c}\text { Companies changing location in 2014 and their target } \\
\text { location in 2016 }\end{array}$ & 69.90 & 80.98 & 8.37 & 11.16 & $4,657.00$ & $4,657.00$ \\
\hline Newly registered companies & 66.43 & 71.43 & 9.36 & 10.84 & $22,331.19$ & $21,830.69$ \\
\hline Deregistered companies & 60.43 & 60.54 & 7.30 & 7.49 & $19,041.50$ & $18,371.81$ \\
\hline Companies with foreign capital & 147.74 & 146.34 & 56.71 & 56.67 & $1,654.00$ & $1,622.56$ \\
\hline Population size & 52.58 & 52.87 & 5.33 & 5.40 & $2,404,912.63$ & $2,402,206.20$ \\
\hline $\begin{array}{c}\text { Size of workforce according to actual place of } \\
\text { performing work }\end{array}$ & 62.49 & 63.79 & 7.39 & 7.69 & $889,840.75$ & $935,275.69$ \\
\hline Size of workforce according to location of seat & 84.80 & 85.78 & 11.42 & 11.75 & $646,237.44$ & $682,546.25$ \\
\hline
\end{tabular}

Source: own analysis on the basis of data from GUS (Central Statistical Office)

Warsaw is the hub that has the largest and most important share in the flows of companies to other cities (see Table 1). Nevertheless, nearly all of the analyzed cities have a negative balance of company relocation with Warsaw (only Katowice reports a small positive balance).

\section{An increase or a drop in spatial differentiation?}

Several conclusions can be drawn from the results presented in Table 2.

The first relates to the scale of regional variations in terms of migration of companies. There are substantial differences between the regions in that respect, but they are still smaller 
than the differences in the distribution of companies with foreign capital; this phenomenon has been a source of contrasts in Poland for many years (Dziemianowicz 1997).

The next conclusion relates to the reason behind the increase in differences between the regions. It is mainly caused by this phenomenon being concentrated in the Mazowieckie voivodeship. This region has for years been rated as the most attractive for potential investors (domestic and foreign) (GodlewskaMajkowska et al. 2017).

The third conclusion relates to the dynamics of changes in regional differences. The extent of change in differences resulting from migration of companies was higher in the (brief) analyzed period than the dynamics of changes in other social and economic phenomena. The coefficient of variation for the migration of companies increased by over 10 percentage points, while changes in this coefficient in the other analyzed variables are of between 1 and 5 percentage points.

The fourth and final conclusion relates to the scale of relocation of companies. It was mentioned in the introduction that migrating companies constitute $1.8 \%$ of all business entities listed in REGON. At the same time, the voivodeship average of migrating companies is almost three times higher than the average of companies with foreign capital, and amounts to $21.3 \%$ of the average of newly registered entities and $25.3 \%$ of the voivodeship average of deregistered entities.

\section{Summary}

The initial hypothesis can be confirmed, that the moving of businesses operating in Poland has increased differences between regions, which means an increased concentration of businesses in several voivodeships.

The analysis presented above shows that the migration of companies results in an increase in inter-regional differences in their distribution. It was proven that the scale of concentration of companies resulting from their migration is higher than the extent of regional variations in terms of other social and economic phenomena. It must be kept in mind that due to data availability, only a short period was analyzed. This study also leads to conclusions on the preferred destinations for relocating companies. Most often companies migrate within their regions. The second preferred destination is the Mazowieckie voivodeship (Warsaw in particular), and the third is regions directly bordering a given voivodeship. These results coincide with the results of research on the location of foreign companies in Polish regions (Domański 2001; Kłysik-Uryszek 2010) as well as the location factors of domestic enterprises within one voivodeship (Dziemianowicz et al. 2012).

Further research on migration of companies should focus on assessment of the size of actual migrations. It is known for a fact that some companies "relocate" only the address of their seat, which is caused by the way in which tax offices operate (there are more audits in regions where there are fewer companies), or because they want to boost the prestige of their business. Still, even a purely bureaucratic change of company address for marketing reasons and convenience does affect the local environment (the company starts paying its taxes elsewhere, which impacts the tax revenues of a given municipality). A detailed analysis of flows of companies between metropolitan cities shows that Warsaw is a hub that usually attracts more companies from other cities than it "gives back". On the other hand, the capital of Poland is an important source of new companies for other cities. Therefore, it seems advisable to carry out further research to determine the industries to which migrating companies belong, because it would allow us to assess whether relocations contribute to some extent to regional specializations.

\section{References}

Almond, P, Ferner, A \& Tregaskis, O 2015, 'The changing context of regional governance of FDI in England', European Urban and Regional Studies, vol. 22(1), pp. 61-76.

Ambroziak, AA 2014, 'The Legal Framework for Regional State Aid in the European Union in 2014-2020 and Its Impact on the Attractiveness of Poland's Regions to Investors' in New Cohesion Policy of the European Union in Poland. How It Will Influence the Investment Attractiveness of Regions in 2014-2020, ed. AA Ambroziak, Springer, Cham Heidelberg New York Dordrecht London, pp. 63-76.

Badri, MA 2007, 'Dimensions of Industrial Location Factors: Review and Exploration', Journal of Business and Public Affairs, vol. 1(2), pp. 1-26.

Bajo-Rubio, O, Díaz-Mora, C \& Díaz-Roldán, C 2010, 'Foreign Direct Investment and Regional Growth: An Analysis of the Spanish Case', Regional Studies, vol. 44(3), pp. 373-382. DOI: 10.1080/00343400802508844.

Canaleta, CG, Arzoz, PP \& Garate, MR 2004, 'Regional Economic Disparities and Decentralisation', Urban Studies, vol. 41(1), pp. 71-94.

Dicken, P 2011, Global Shift. Mapping the Changing Contours of the World Economy, The Guildford Press, New York, London.

Domański, B 2001, Kapitał zagraniczny w przemyśle Polski. Prawidłowości rozmieszczenia, uwarunkowania i skutki [Foreign capital in Polish industry. Regular distribution, conditions and effects], Uniwersytet Jagielloński, Instytut Geografii i Gospodarki Przestrzennej, Kraków.

Dunning, JH \& Lundan, SM 2008, Multinational Enterprises and the Global Economy, Second Edition, Edward Elgar, Cheltenham and Northampton.
Dziemianowicz, W 1997, Kapitał zagraniczny a rozwój regionalny i lokalny w Polsce [Foreign capital and regional and local development in Poland], Studia regionalne i lokalne, EUROREG, Warszawa.

Dziemianowicz, W, Mackeiwicz, M \& Zaleski, J 2012 'Konkurencyjność Mazowsza i jej uwarunkowania' [Competitiveness of Mazovia and its determinants], Trendy Rozwojowe Mazowsza, no. 5, pp. 7-44.

Eriksson, RH, Hansen, HK \& Lindgren, U 2014, 'The Importance of Business Climate and People Climate on Regional Performance', Regional Studies, vol. 48(6), pp. 1135-1155. DOI: 10.1080/00343404.2013.770140.

Fallon, G \& Cook, M 2010, 'Exploring the Regional Distribution of Inbound Foreign Direct Investment in the UK in Theory and Practice: Evidence from a Five-Region Study', Regional Studies, vol. 44(3), pp. 337-353. DOI: 10.1080/00343400802378735.

Foray, D 2015, Smart Specialization. Opportunities and Challenges for Regional Innovation Policy, Routledge, London and New York.

Gawlikowska-Hueckel, K 2003, Procesy rozwoju regionalnego w Unii Europejskiej. Konwergencja czy polaryzacja? [Regional development processes in the European Union. Convergence or polarization?] Wydawnictwo Uniwersytetu Gdańskiego, Gdańsk.

Godlewska-Majkowska, H, Komor, A, Pilewicz, T, Turek, D, Żukowska, J, Zarębski, P, Czernecki, M, Miąsek, D \& Typa, M 2017, Atrakcyjność inwestycyjna regionów 2017 [Investment attractiveness of regions 2017], Szkoła Główna Handlowa w Warszawie, Warszawa. 
Grabow, B, Henckel, D \& Hollbach-Grömig, B 1995, 'Weiche Standortfaktoren', Schriften des Deutschen Institut für Urbanistik, Band 89, Stuttgart-Berlin-Köln.

Hilber, ChAL \& Voicu, I 2009, 'Agglomeration Economies and the Location of Foreign Direct Investment: Empirical Evidence from Romania', Regional Studies, vol. 44(3), pp. 355-371. DOI: $10.1080 / 00343400902783230$.

Hudson, R 2000, Production, Places and Environment. Changing Perspectives in Economic Geography, Pearson Education Limited, Essex.

Jarczewski, W 2012, Pozyskiwanie inwestorów do gmin [Acquiring investors to municipalities], Wolters Kluwer Polska Sp. z o.o., Warszawa.

Kłysik-Uryszek, A 2010, Bezpośrednie inwestycje zagraniczne $w$ gospodarce regionu. Teoria i praktyka [Foreign direct investments in regional economy. Theory and practice], CeDeWu Sp. z o.o., Warszawa.

McCann, P \& Sheppard, S 2003, 'The Rise, Fall and Rise Again of Industrial Location Theory', Regional Studies, vol. 37(67), pp. 649-663.

Myrdal, G 1957, Rich Lands and Poor: The road to World Prosperity, Harper and Row, New York.

Porter, ME 2001, Porter o konkurencji [Porter on Competition], Polskie Wydawnictwo Ekonomiczne, Warszawa.

Schmenner, RW, Huber, JC \& Cook, RL 1987, 'Geographic differences and the location of new manufacturing facilities', Journal of Urban Economics, vol. 21(1), pp. 83-104.
Stafford, HA 1972, 'The geography of manufacturers', Progress in Geography, vol. 4, pp. 181-215.

Strahl, D (ed.) 2006, Metody oceny rozwoju regionalnego [Methods for assessing regional development], Wydawnictwo Akademii Ekonomicznej im. Oskara Langego we Wrocławiu, Wrocław.

Vanhove, N 1999, Regional Policy: A European Approach, Ashgate Publishing Ltd, Aldershot.

Walmsley, DJ \& Lewis, GJ 1997, Geografia człowieka. Podejścia behawioralne [Human geography. Behavioral approach], Wydawnictwo Naukowe PWN, Warszawa.

Weber, A 1909, Uber den Standort der Industrien, Tubingen.

Wilk, W 2001, Czynniki lokalizacji i rozmieszczenie wybranych usług w Warszawie [Location factors and distribution of selected services in Warsaw], Uniwersytet Warszawski, Wydział Geografii i Studiów Regionalnych, Warszawa.

Wołowiec, T \& Skica, T 2013, 'The Instruments of Stimulating Entrepreneurship by Local Government Units (Lgu's)', Ekonomska Istraživanja-Economic Research, vol. 26(4), pp. 127-146. 